\title{
The Relationships Between Physical Environmental Conditions of House with Pneumonia Incidence on Children Under Five Years, in the Working Area of Ngesrep Health Centre, Semarang City
}

\author{
Mifta Rahmiza1, Suhartono ${ }^{2}$, and Nurjazuli² \\ ${ }^{1}$ Postgraduate Student Faculty of Public Health, Universitas Indonesia, Depok, Indonesia \\ ${ }^{2}$ Diponegoro University Semarang, Indonesia
}

\section{Abstract}

Pneumonia is the main cause of infant mortality in the world. Every year there are 9 million total infant deaths where more than 2 million children under five years old die from pneumonia. Child mortality due to pneumonia in Indonesia amounted to $1.19 \%$.

Corresponding Author:

Mifta Rahmiza

miftarahmiza14@gmail.com

Received: 26 December 2018

Accepted: 23 February 2019

Published: 7 March 2019

Publishing services provided by Knowledge E

(c) Mifta Rahmiza et al. This article is distributed under the terms of the Creative Commons

Attribution License, which permits unrestricted use and redistribution provided that the original author and source are credited.

Selection and Peer-review under the responsibility of the 2 nd International Meeting of Public Health 2016 Conference Committee. In 2013, the city of Semarang got the highest incidence of pneumonia that found in Puskesmas Ngesrep Semarang City in the amount of 379 cases. One of the risk factors pneumonia in children under five years old is the physical environment of the house. This study aims to determine the relationship between the physical environment home with pneumonia on infants in Puskesmas Ngesrep Semarang. This research uses an observational, analytical study with a case-control study. The sample in this study amounted to 82 toddlers aged 12-59 months consisting of 41 cases, and 41 controls were carried out at a variable matching age and sex of children. Chi-square test used as data analysis with $95 \%$ confidence level. The results showed that among 9 independent variables studied, there are 5 variables associated with the incidence of pneumonia in infants, it was widely ventilation $(p=0.026$; OR $=3.041)$, temperature $(p=0.008$; OR $=$ 3.776), lighting $(p=0.006 ; O R=4.117)$, humidity $(p=0.023 ; O R=3.255)$, and population density $(p=0.007$; OR $=3.850)$. From this study, we can conclude that house physical environmental conditions associated with the incidence in infant's pneumonia consists of ventilation, temperature, lighting, humidity, and population density.

Keywords: Physical environment of the house; pneumonia; children under five year

\section{Introduction}

Acute Lower Respiratory Infections (ALRI) is a disease of the respiratory tract caused S OPEN ACCESS by the infectious agent which transmitted from human to human beings (WHO 2007). Pneumonia is a condition where the alveoli on one or two lungs fully charged by the 
fluid that disrupts the exchange of oxygen that makes it difficult to breathe (UNICEF 2006).

Pneumonia is a major cause of death in the world especially among children under the age of five years (Black et al. 2003). Based on a report from The United Nations Children's Fund (UNICEF) and the World Health Organization (WHO) pneumonia is the leading killer of infants in the world, more than with the combination of the disease Acquired Immune Deficiency Syndrome (AIDS), malaria and measles. Each year expected to more than 2 million infants died because of pneumonia ( 1 infants/20 second) from 9 million total death of infants in the world (WHO 2007).

The highest incidence of pneumonia in the Asian region occurred in parts of South Asia, including Indonesia. Indonesia occupies the most elevated position to six with the amount of 6 million cases. ${ }^{4}$ Based on the results of the Riset Kesehatan Dasar (Riskesdas) 2013 period prevalence and the prevalence of pneumonia in Indonesia each of 1.8 percent and 4.5 percent and over the last few years the scope of the discovery of pneumonia has never reached national targets, including target 2013 that $80 \%$ (Kemenkes RI 2013; Kemenkes RI 2014).

Period prevalence and the prevalence of pneumonia Central Java Province 2013 by 1.9 percent and 5.0 percent.7 in the City of Semarang especially respiratory disease pneumonia is still a significant public health problem. Incidence Rate (IR) pneumonia and severe pneumonia in 2013 at 258 per 10,000 infants increase compared to 2012 amounting 246/10,000 infants (Dinas Kesehatan Kota Semarang 2014).

Based on the Health Office data City of Semarang 2013 the discovery of the highest number of cases pneumonia in the City of Semarang there in the clinic in the sub-district of Banyumanik Ngesrep 379 (92\%) than expected infants as much as 4.112 infants. The clinic Ngesrep is one of the clinic with numbers pneumonia high enough each year, in 2011 the number of cases of pneumonia there are as many as 418 (126\%) than expected infants as much as 3.324 cases and decline in 2012 with the situation as much as 332 (81\%) than expected infants as much as 4,112 cases, they have increased to 379 cases (92\%) than expected infants as much as 4,112 infants in 2013 (Dinas Kesehatan Kota Semarang 2014).

Factors causing pneumonia consists of two large groups become the risk factors related to the Genesis pneumonia intrinsic factors and factors external components. Fundamental factors include age, gender, nutritional status, low birth weight, immunization status, breastfeeding and the giving of vitamin A. Factors extrinsic elements include the density population, air pollution, house type, ventilation humidity, kitchen layout, fuel type, drug use of mosquitoes, smoke, family income and maternal factors good education, the age of the mother and the knowledge of the mother. One of the media source 
of diseases pneumonia is the physical condition of the home and its surroundings which is a place of shelter and interact directly with its inhabitants (Departemen Kesehatan RI 2000).

\section{Methods}

This research observational and analytical with a case-control approach. The subject of the study consists of 2 groups of cases and control groups with samples of each group is 41 - the case data and pneumonia control infants obtained from data registration Puskesmas Ngesrep disease. Examples of cases are under five months 12-59 old who suffered from pneumonia at period December to February 2015, while the age of 1259 months that do not suffer from pneumonia. A free variable examined consists of full ventilation temperature, lighting, humidity, type of walls, type of floor, the existence of smoke hole kitchen, shelter, density and the presence of smokers. In this research done disturbing variable control, age, and gender did match, while immunization status and nutritional status done by control restrictions. Loading data obtained through interview of semi-structured, observation and measurement of the condition of the physical environment of the house. The analysis is done to find the relationship between the risk factors with the effect of using test Chi-Square and know the higher the risk to suffer from pneumonia using the Odds Ratio (OR).

\section{Results and Discussion}

This research was done in the working area of the clinic Ngesrep City of Semarang. The working area of the clinic Ngesrep consists of 3 districts, namely Sumurboto, Ngesrep, Tinjomoyo.

The results of the study showed that the average age of infants in the case group is 32,80 months while the average age of infants in the control group is 33.15 months. The age of infants under the youngest on the case group is 14 months while in the control group is 13 months. Early childhood age group is the oldest in the group. The case is 57 months while in the control group is 58 months.

Based on sex, men and women each have the same proportion. Infants of type gender boys in the case group and the control of 22 infants (53.7\%) while the type of female on the case group and control as much as 19 infants (46,3\%). While the instructions we have concerning immunization and nutritional status of infants in the case group and control groups have been doing complete vaccination (measles and Voter List and have the state of proper nutrition (100\%). 
The current situation of the environment around the house that there is no existence of the trees obtained the result that the condition of the environment around the home of infants who do not there is the existence of the tree has the proportion as much as 32 house $(78.0 \%)$ on case groups while in the control group as many as 35 homes (85.4\%). Meanwhile the condition of the environment around the house that there is the existence of the buildings around the house have proportion as much as 16 house (39.0\%) on case groups while in the control group as many as 12 homes (29.3\%).

A free variable examined consists of 9 variables which are analyzed using Chi-Square tests using a $95 \%$ confidence interval.

In this research, there are five free variables related to the Genesis pneumonia on infants in the working area of the clinic Ngesrep City of Semarang, namely: full ventilation temperature, lighting, humidity, density shelter. Based on the test Chi-Square obtained the value of $\mathrm{p}$ value $=0.026$; Odds Ratio $(\mathrm{OR})=3.041 ; 95 \% \mathrm{Cl}=1.230-7.515$ can interpret that there is a significant relationship between extensive ventilation with genesis pneumonia in infants. Ventilation has a function as a means of circulating fresh air into the house and dirty air out of the house with the aim to maintain the moisture of the air in the room. The house that not equipped with ventilation means will cause the supply of fresh air in the house to become very minimum. The exchange of air that does not meet the conditions can cause sprouting growth of microorganisms that can cause disturbance of health problems one namely microorganisms to cause pneumonia. Now the wide house ventilation that meets the conditions that are at least Ten percent of the floor area with critical ventilation system (Kepmenkes RI 2011).

Test results obtained temperature variable statistics value of $p$-value $=0.008$; Odds Ratio $(O R)=3.776 ; 95 \% \mathrm{Cl}=1.505-9.475$ can be interpreted that there is a significant relationship between the temperature with genesis pneumonia in infants. The air temperature in the house is high can allow bacteria to grow and multiply by both in the home. Bacteria causes pneumonia, e.g., Haemolytic pneumonia, have a vulnerable preferred temperature, but in this range, there is an optimum temperature where the bacteria are growing to grow dramatically. Hemolytic pneumonia can grow in the temperature range $25^{\circ} \mathrm{C}-40{ }^{\circ} \mathrm{C}$ but could grow optimally at a temperature $31^{\circ} \mathrm{C}$ to $37^{\circ} \mathrm{C}$ (Sari 2014).

The lighting in this research obtained the value of $p$-value $=0.006$; Odds Ratio (OR) $=4.117 ; 95 \% \mathrm{Cl}=1.575-10.764$ can be interpreted that there is a significant relationship between the lighting with genesis pneumonia in infants. Infants who lived in the house with the light that does not meet the conditions have the risk of 4.117 times greater suffering from pneumonia compared with infants who lived in the house with the lighting that meets the requirements. 
TABLE 1: Analysis of the Relationship of the Condition of the Physical Environment of the House with the Genesis Pneumonia on Infants in the Working Area of the Clinic Ngesrep City of Semarang.

\begin{tabular}{|c|c|c|c|c|c|}
\hline \multirow{2}{*}{$\begin{array}{l}\text { The physical } \\
\text { environment of the } \\
\text { House }\end{array}$} & \multicolumn{2}{|c|}{ The case $(n=41)$} & \multicolumn{2}{|c|}{ Control $(n=41)$} & \multirow[t]{2}{*}{$p$ value } \\
\hline & $\mathbf{F}$ & $\%$ & $\mathbf{F}$ & $\%$ & \\
\hline \multicolumn{6}{|l|}{ Wide Ventilation } \\
\hline Does not qualify & 28 & 68,3 & 17 & 41.5 & 0.026 \\
\hline Qualify & 13 & $\begin{array}{l}\text { Fell } 24.1 \\
\text { pct. coal }\end{array}$ & 24 & 58.5 & \\
\hline \multicolumn{6}{|l|}{ The temperature } \\
\hline Does not qualify & 29 & 70.7 & 16 & 39.0 & 0.008 \\
\hline Qualify & 12 & 29.3 & 25 & 61.0 & \\
\hline \multicolumn{6}{|l|}{ The lighting } \\
\hline Does not qualify & 32 & 78.0 & 19 & 46.3 & 0.006 \\
\hline Qualify & 9 & 22.0 & 22 & 53.7 & \\
\hline \multicolumn{6}{|l|}{ Humidity } \\
\hline Does not qualify & 31 & 75.6 & 20 & 48.8 & 0.023 \\
\hline Qualify & 10 & $24.4 \mathrm{mph}$ & 21 & 51.2 & \\
\hline \multicolumn{6}{|l|}{ The type of wall } \\
\hline Does not qualify & 6 & 14.6 & 2 & 4.9 & 0.264 \\
\hline Qualify & 35 & 85.4 & 39 & 95.1 & \\
\hline \multicolumn{6}{|l|}{ Type of floor } \\
\hline Does not qualify & 1 & 2.4 & 1 & 2.4 & 1.000 \\
\hline Qualify & 40 & 97.6 & 40 & 97.6 & \\
\hline \multicolumn{6}{|l|}{$\begin{array}{l}\text { The existence of the } \\
\text { hole kitchen smoke }\end{array}$} \\
\hline No & 6 & 14.6 & 4 & 9.8 & 0.736 \\
\hline No & 35 & 85.4 & 37 & 90.2 & \\
\hline \multicolumn{6}{|l|}{ The density of shelter } \\
\hline Does not qualify & 24 & 58.5 & 11 & 26.8 & 0.007 \\
\hline Qualify & 17 & 41.5 & 30 & 73.2 & \\
\hline \multicolumn{6}{|l|}{$\begin{array}{l}\text { The existence of } \\
\text { smokers }\end{array}$} \\
\hline No & 30 & 73.2 & 26 & 63.4 & 0.476 \\
\hline No & 11 & 26.8 & 15 & 36.6 per & \\
\hline
\end{tabular}

The light of the sun useful as the explanation, the light of the sun also serves as the ultraviolet light that has a wavelength $<290 \mathrm{~nm}$. Ultraviolet light in wavelength 253.7 $\mathrm{nm}$ can kill germs and bacteria, viruses and fungi that can cause infection and allergy, asthma and other diseases. Ultraviolet light will damage the DNA of microbes (germs, bacteria, viruses, and fungi) so that the DNA of the microbes become sterile. If these microbes are affected by ultraviolet light, then the microbes are not able to reproduce and eventually die (Sari 2014). 
TABLE 2: Results of the Odds Ratio and 95\% Confident Physical Environment Interval House.

\begin{tabular}{l|c|c|}
\hline The physical environment of the House & OR & 95\% Cl \\
\hline Wide ventilation & 3.041 & $1.230-7.515$ \\
\hline The temperature & 3.776 & $1.505-9.475$ \\
\hline The lighting & 4.117 & $1.575-10.764$ \\
\hline Humidity & 3.225 & $1.272-8.330$ \\
\hline The type of wall & 3.343 & $0.633-17.653$ \\
\hline Kind of floor & 1.000 & $0.060-16.548$ \\
\hline The existence of the hole kitchen smoke & 1.586 & $0.412-6.098$ \\
\hline The density of shelter & 3.850 & $1.520-9.750$ \\
\hline The presence of smokers & 1.573 & $0.615-4.023$ \\
\hline
\end{tabular}

Research in the working area of the clinic Ngesrep City of Semarang proves no moisture relationship with genesis pneumonia in infants. Test results obtained statistics value of $p$-value $=0.023 ;$ Odds Ratio $(\mathrm{OR})=3.255 ; 95 \% \mathrm{Cl}=1.272-8.330$.

Humidity can be influenced by temperature, the intensity of the lighting, ventilation is not good, floor and is not waterproof. The house of moisture allows for rats and cockroaches carry bacteria and viruses that can be triggered the respiratory disease and can reproduce in the room. Viruses and bacteria can grow optimally at a temperature above $30{ }^{\circ} \mathrm{C}$ and moisture above $60 \%$. Air humidity in the rooms which is not good to become a good media for the growth of bacteria causes pneumonia (Sari 2014).

Most of the cases of infants and children under five have control type of the walls of the house that have been qualify. Test results variable statistics type of walls obtained the value of $p$-value $=0.264$; Odds Ratio $(O R)=3.343 ; 95 \% \mathrm{Cl}=0.633-17.653$ can interpret that there are no significant relationships between the type of walls with genesis pneumonia in infants. The walls of the house that does not meet the conditions causing the moisture in the room became not normal. Humidity is not normal this will be a precondition the growth of bacteria or pathogen bacteria that can cause the disease for the inhabitants (WHO 2007).

Urban communities on the majors have a type of floor that has been qualify. In this research, it is known that there is no relationship between the type of the wall with the genesis pneumonia in infants. Based on the review of the statistics obtained the value of $\mathrm{p}$-value $=1.000$; Odds Ratio $(\mathrm{OR})=1.000 ; 95 \% \mathrm{Cl}=0.060-16.54$ (Dinas Kesehatan Kota Semarang 2014).

Based on theory, the type of floor can influence genesis pneumonia in infants. Infants more often play on the level, if the story of the house made from the ground will be more often and quickly dirty so that is the window the entry of germs or bacteria into the body of infants and can cause diseases. The condition of the floor can be a risk factor for 
pneumonia disease. Respondents type of level his house from the ground directly the state of the story of the house was also dirty and damp cloth (Mokoginta 2013).

Based on the review of the statistics known that there is no relationship between the existence of smoke hole kitchen with genesis pneumonia on infants in the working area of the clinic the Ngesrep City of Semarang. Based on the test Chi-Square obtained the value of $p$-value $=0.736$; Odds Ratio $(O R)=1.586 ; 95 \% \mathrm{Cl}=0.412-6$, redemptive. Based on observation results in the field a little found the house of respondents cases and controls that there is no existence of smoke hole kitchen. The majority of respondents had recognized the main function of the creation and ventilation holes' kitchen smoke.

In theory, the existence of the hole kitchen smoke is a risk factor of pneumonia because the hole kitchen smoke can function as the air circulation while cooking. The kitchen smoke confined in the house can pose a risk of pneumonia, especially for infants. It because of the existence of air vents in the kitchen related to the reduction of the concentration of the particle emissions from smoke the remaining combustion.

Based on the test Chi-Square obtained the value of $\mathrm{p}$-value $=0.007$; Odds Ratio (OR) $=3.850 ; 95 \% \mathrm{Cl}=1.520-9.750$ can interpret that there is a significant relationship between the density of shelter with genesis pneumonia in infants. Infants who lived in the house with the frequency of accommodation does not qualify a risk 3.850 times greater suffering from pneumonia compared with infants who lived in the house with the density of shelter qualify.

The density of shelter including an essential factor that has a relationship with genesis pneumonia. The frequency is a pre-requisite for the process of the transmission of the disease, more crowded then viral diseases especially the disease through the air will be more comfortable and faster.12 Density shelter that does not meet the requirements will affect the amount of the colony microorganism cause infectious diseases such as respiratory tract. In the house of a small companion of many will affect the air quality in the home (Soesanto et al. 2000).

The existence of smokers in the house on this research shows that there is no relationship between the existence of smokers with genesis pneumonia in infants. Based on Chi-Square obtained the value of $\mathrm{p}$-value $=0.476$; Odds Ratio $(\mathrm{OR})=1.573 ; 95 \% \mathrm{Cl}=$ $0.615-4.023$.

In theory, air pollution by carbon monoxide (CO) occurs during smoking. Smoke contains $\mathrm{CO}$ with the concentration of more than 20,000 ppm during is reinvested masses and then diluted to $400-500 \mathrm{ppm}$. The focus of $\mathrm{CO}$ is high in the smoke that inhalation causes the level of $\mathrm{COHb}$ in the blood increases, so that interferes with the process of respiratory allergies. Thus the smoke is hazardous for smokers or people who are around smokers (such as secondhand) (Fahimah 2014). 
The incompatibility research results with the theory probably caused by two factors, first answers Respondents varied so that makes it difficult for the researchers to qualify existence of smokers what do the activity of smoking in the house or smoking but done outside the house with so the determination of the existence of smoke exposure is not fully qualified accurately. Secondly, because of the lack of comprehensive information related to the behavior of smokers, such as the number of cigarettes consumed per day, the type of cigarettes and smoking intensity so that the effect of smoke exposure to the other household members especially infants cannot be known.

\section{Conclusions}

The condition of the physical environment of the house related to the Genesis pneumonia among children under five in the clinic the Ngesrep City of Semarang is extensive ventilation temperature, lighting, moisture and shelter density.

\section{References}

[1] Black RE, Morris SS, Bryce J. 2003. "Where and why are 10 million children dying every year." Lancet 361(9376):2226-2234.

[2] Departemen kesehatan Republik Indonesia. 2000. Pedoman Program Pemberantasan Penyakit Infeksi Saluran Pernafasan Akut untuk Penanggulangan Pneumonia Pada Balita. Jakarta: Ditjen PPM dan PLP.

[3] Dinas Kesehatan Kota Semarang. 2014. Profil kesehatan Kota Semarang 2013. Semarang: Dinas Kesehatan Kota Semarang.

[4] Fahimah R. 2014. "Kualitas Udara Rumah dengan Kejadian Pneumonia Anak Bawah Lima Tahun (di Puskesmas Cimahi Selatan dan Leuwi Gajah Kota Cimahi)." Makara J. Health : Vol. 18 No. 1 : 25-33. 2014.

[5] Kementerian Kesehatan Republik Indonesia. 2013. Pokok - Pokok Hasil Riskesdas Provinsi Jawa Tengah 2013. Jakarta: Badan Penelitian dan Pengembangan Kesehatan Kementerian Kesehatan RI.

[6] Kementerian Kesehatan Republik Indonesia. 2013. Riset Kesehatan Dasar 2013. Jakarta: Kementerian Kesehatan RI.

[7] Kementerian Kesehatan Republik Indonesia. 2014. Profil Kesehatan Indonesia 2013. Jakarta: Kementerian Kesehatan RI.

[8] Kepmenkes RI. 2011. Nomer 1077/Menkes/PER/V/20011 tentang Pedoman Penyehatan Udara Dalam Ruang Rumah. Jakarta: Kementerian Kesehatan RI. 
[9] Mokoginta D. 2013. Faktor Risiko Kejadian Pnemonia Pada Anak Balita Di Wilayah Kerja Puskesmas Sudiang Kota Makassar. Fakultas Kesehatan Masyarakat Universitas Hassanudin.2013.

[10] Sari EL. 2014. "Hubungan Antara Kondisi Lingkungan Fisik Rumah dengan Kejadian Pneumonia pada Balita di Wilayah Kerja Puskesmas Pati I Kabupaten Pati." Jurnal Kesehatan Masyarakat (e-Journal), 2014; 2(1) Hal: 56-61.

[11] Soesanto SS, Lubis A, Atmosukarto K. 2000. "Hubungan Kondisi Perumahan dengan Penularan Penyakit ISPA dan TB Paru." Artikel: Media Litbang Kesehatan. Vol.2 No. X No. 27-31. 2000.

[12] UNICEF. 2006. The Pneumonia Forgotten Killer of Children. WHO.

[13] WHO. 2007. Infection prevention and control of epidemic-and pandemic-prone acute respiratory diseases in health care. WHO Interim Guidelines, June 2007. Jenewa: WHO. 